\title{
Medical students on the value of role models for developing 'soft skills' -
} "That's the way you do it" \author{
${ }^{1}$ Department of Psychiatry, Faculty of Health Sciences, University of Pretoria, South Africa \\ ${ }^{2}$ Education Office, Faculty of Health Sciences, University of Pretoria, South Africa \\ ${ }^{3}$ Education consultant, Faculty of Health Sciences, University of Pretoria, South Africa \\ ${ }^{4}$ Social Science Research Consultancy (SSRC), Pretoria, South Africa \\ ${ }^{5}$ Deputy Dean, Faculty of Health Sciences, University of Pretoria, South Africa \\ ${ }^{6}$ School of Medicine, Faculty of Health Sciences, University of Pretoria, South Africa
}

PIM Joubert ${ }^{1}$, C Krüger ${ }^{1}$, A-IM Bergh ${ }^{2}$, GE Pickworth ${ }^{3}$, CWVan Staden ${ }^{1}$, JL Roos $^{1}$, WJ Schurink ${ }^{4}$, RR Du Preez ${ }^{1}$, SV Grey ${ }^{5}$, BG Lindeque $^{6}$

\begin{abstract}
Objective: The Soft Skills Project examined the professional development of medical students at the University of Pretoria, especially their doctor-patient interaction skills and professional socialisation. This paper reports on one of the findings of the project, namely the importance that medical students attach to role models in the development of soft skills. Methods: We used a qualitative method with symbolic interactionism and grounded theory as framework. Fourty two final-year students from the last cohort following the traditional curriculum at the University of Pretoria in 2001, and 49 final years from the first cohort following the reformed curriculum in 2002 were recruited. Data were collected by applying focus groups, in-depth, individual interviews, as well as autobiographical sketches. Data were captured by means of audio tape recordings, transcripts of the tapes, researchers' field notes, and written accounts by students, and were analysed by using a general inductive approach. Results: There were no striking differences between the comments of the two groups. Students considered registrars to be the most influential role models in the clinical teaching context, followed by specialist consultants. Their idea of a good role model was a clinically and academically competent doctor that cared about patients, had good interpersonal skills, and who could inspire students. Students needed and appreciated good role models to help them to develop their own soft skills. They expected guidance and behavioural examples from clinical teachers. Although there were competent role models, the students were exposed to poor role models. Poor role models mainly affect students negatively. Students tend to imitate and perpetuate unacceptable behaviour. Furthermore, poor role models have a negative emotional effect on students and are detrimental to their moral and learning environment. Sometimes, poor role models have a paradoxical positive effect in the sense that they inform students how not to behave. Conclusion: Medical schools and medical doctors working with medical students should be consciously aware of the importance of role models both when allocating clinical teachers to students, and while performing duties with students. It is especially necessary to realise that poor role modelling has important detrimental effects on students. Therefore, an attempt should be made to ensure that not only clinical examination skills, but also soft skills, are demonstrated at the bedside. Measures to ensure adequate exposure of students to positive role models could include: staff development; the identification of good role models to guide registrars; and a reallocation of tasks, where possible, to increase the exposure of students to the 'natural' role models.
\end{abstract}

Keywords: Soft skills; Role models; Medical students; Professionalism

Received: 02.12.04

Accepted: 13.06 .05

\section{Correspondence:}

Dr PM Joubert

Department of Psychiatry, Faculty of Health Sciences,

University of Pretoria,

PO Box 667, Pretoria, 0001, South Africa

email: pm.j@icon.co.za

\section{Introduction}

The Soft Skills Project examines the professional development of medical students, especially their doctor-patient interaction skills and professional socialisation. There is no ultimate definition of soft skills, but they include such skills as ethics, attitudes, interpersonal abilities, communication, and being a life long learner. Here we will simply summarise: soft skills are 
"doing the right thing at the right time, and doing it nicely," ${ }^{1}$ in a clinical context.

According to the views of both the medical profession ${ }^{2,3}$ and research ${ }^{4-7}$, role models are important for the professional socialisation of medical students. Mufson, for example, states that "physicians must do more than talk about professionalism; they must live it."' Research also indicates the importance of role models for teaching medicine, related behaviours (which include soft skills) $)^{6,7}$, as well as their influence on students' later career choices. ${ }^{4,5,8}$ Students evaluate their clinical teachers not only on their practical clinical skills, but also on their soft skills.

The aim of this paper is to present medical students' views of role models and their effect on students' personal and professional development, reporting on one of the findings of the Soft Skills Project at the Faculty of Health Sciences, University of Pretoria.

\section{Method}

A qualitative method was used with symbolic interactionism and grounded theory as framework. Very basically, grounded theory ${ }^{9,10}$ strives toward the generation of a substantive theory concerning peoples' subjective experiences. It is based on themes that emerged from their everyday experiences and viewpoints. Symbolic interactionism ${ }^{11}$ entails the assumptions that people (i) define themselves and make sense of their world through their interaction with others, (ii) develop shared definitions since they undergo similar experiences, and (iii) when studying their behaviour researchers must employ methods enabling them to understand the definitions they continuously create and modify. ${ }^{12}$

Forty two final-year students from the last cohort following the traditional curriculum at the University of Pretoria in 2001, and 49 final years from the first group following the reformed curriculum in 2002, were recruited by means of purposive and theoretical sampling. With purposive sampling one selects those cases of the population under study one believes to be especially informative (in this case certain students).

Theoretical sampling represents the strategy by means of which one purposively sample groups. Then, based on the data and insights one gathers from them, one further selects subjects that one believes can shed light on these "discoveries". This process is continued until no new findings are found.

Data was collected by the following qualitative methods: focus groups, in-depth individual interviews, and autobiographical sketches. The data was captured by using audio tape recordings, transcripts of the tapes, researchers' field notes, and written accounts requested from some students. As far as analysis is concerned an inductive approach was generally applied, that is, general principles and concepts were inferred from the data. However, reasoning was on occasion deductive, since abstract constructs were also used to derive hypotheses.

\section{Results}

As was the case with the analysis of students' experience of the development of their soft skills and their professional identity, there were no striking differences between the themes and patterns emerging from the data generated through the interaction with the two curriculum groups with regard to role models. The findings from the two groups will therefore be discussed together.

From the analysis of the data it became apparent that almost all participants thought that soft skills could be developed, more so during ward rounds and other clinical activities than during formal lectures. According to the students' responses many factors play a role in developing soft skills. Examples are: significant events, exposure to patients, own experience, peer discussion, personal values, and background. Role models and patient contact emerged as the two most significant ways of learning soft skills. This paper will focus on role models.

\section{"Role models are very important"}

Although formal lectures and tutorials were considered important and necessary ${ }^{13}$ for the preparation of studentpatient interaction, students wanted to observe the practice of good soft skills in action. The behaviour of clinical teachers became the standard against which students benchmarked themselves:

Behaviour is learnt primarily by example. What is experienced in the wards becomes the frame of reference for the young doctor's future mannerisms; it is his or her yardstick. If this example is poor or indeed nonexistent, the student never has this yardstick with which to compare his own behaviour.

The experienced clinician is expected to be a guide for dealing with a variety of patients, especially difficult ones:
Mense wat dominerend is, ou mense, belangrike mense in die samelewing... En dan om die leiding by sulke mense [experienced clinicians] te neem. [People that are domineering, old people, people that are important in society... And then to be guided by such people (experienced clinicians).]

\section{Who are the role models?}

The participants mentioned a variety of persons who could become role models, for example general practitioners accommodating students for their preceptorship, family members who are medical doctors, and to a lesser degree senior medical students. Registrars and consultants were however considered to be the most prominent role models.

\section{- The significance of registrars - "I came to know the registrars as people"}

Students spend most of their clinical time under the supervision of a registrar. In the current study this was evident by the frequency of references to registrars and the role they played in the education and development of medical students.
You've got an excellent clinical assistant [registrar], then your block is made, you know, because you're learning a lot not only practically, but [also] how that person deals with another person... 
As registrars are also students, albeit postgraduate, the undergraduate students could relate to them more easily, and could come to know them as people:

Terwyl die kliniese assistente het ek as mense leer ken. En ek het gesien hoe hulle hul eie persoonlikhede aanpas by pasiënte... [While I came to know the registrars as people, and I saw how they adapted their own personalities with patients...]

- Consultants as role models - "Each professor has his things about him that you can take and use"

Participants reported more distance between themselves and consultants. Consultants' knowledge and practical skills were perhaps sometimes just too good and far removed from their reality:

Ek het partykeer gevoel dat alhoewel hulle [konsultante] baie goeie voorbeelde van goeie bedside manners geopenbaar het, het dit nie so 'n groot indruk op my gemaak nie omdat dit amper was soos om televisie te kyk; -asof dit 'n jarelange ingeoefende ding is waarmee hulle nog nooit gesukkel het nie. [I sometimes felt that, although they (consultants) were excellent examples of good bedside manners, I was not very impressed, because it was nearly like watching television. It was as if it were something that had been practised in over many years and with which they had never struggled.]

Despite the perceived distance from the consultants, the students regarded them as important. They scrutinised their clinical teachers from very early on and "sonder dat hulle dit weet, sien jy hoe hulle mense behandel, hoe hulle praat [without them knowing, you see how treat people, and how they talk]". They judged their teachers not only on their clinical expertise, but also on their soft skills competencies.

Voor ons enige lesing gehad het aangaande wat sagte vaardighede behels, het mens alreeds klinici gekategoriseer op grond van hul ooglopende kliniese vermoëns, maar sekerlik ook op die wyse waarop hulle pasiënte hanteer in hul daaglikse omgang. [Before we had any lectures concerning what soft skills involve, we already categorised clinicians (not only) on their obvious clinical abilities, but indeed (also) on the way they treated patients in their daily interactions.]

"He's everything!" - on good role models

The students' idea of a good role model was a doctor who was clinically and academically competent, who had the patient's best interest at heart, who had good interpersonal competence, and who had an ability to inspire students. Some of the attributes appreciated by the students include:
Respect ... academic knowledge... compassion ... those three qualities in a person make them role models.

Somebody who is inspired and inspiring in what they do - that they work hard and their aims are actually to the benefit for the patient.

Students undoubtedly appreciate clinical teachers who are good role models, even more so when they also treated students well. For example, "He gives you encouragement. He tells you how to deal with a patient. He is a very softhearted person. He's a teacher. He's a parent. He's everything!'” The impact is indeed positive: "Dis een van die mense aan wie ek altyd vorentoe sal terugdink - dis hoe jy dit doen. [It is one of the people I'll always remember in future - that's the way you do it]"

"That is how I would like to be" and "How not to be a doctor" students learning from role models

Students learned from doctors as they observed them while they were teaching.

You get some of the consultants, even if they are booked with us [meaning times when consultants are training students], they are incredible with patients. They are very empathetic. So you learn by observing them.

Ek het geleer deur voorbeeld, deur te sien in die saal hoe mense werk. As iemand goed werk met pasiënte en jy kan sien die pasiënt is tevrede, dan maak jy vir jouself [uit], jy weet dis hoe ek wil wees. [I learned by example. By seeing how people work in the ward. If someone works well with patients and you see that the patient is satisfied, then you decide for yourself that it is the way you want to be.]

Students not only observed the practice of soft skills by clinical teachers, but they also "take on those aspects". Specific people may even inspire them to specialise in their field of study - "You walk out of that block, you feel you want to become a [clinician in that department] ... It is just so nice!"

Many students mentioned that explaining things to patients is an important soft skill. Doctors' doing so was appreciated.

And there have been doctors that would sit down with patients and draw pictures and explain to them... That is great.

Then they also explain to the patient what they are going to do. Even if it is a minor thing like drawing blood.

Students had noticed both that doctors did not explain things, "Hy het glad nie aan die pasiënt verduidelik wat hy beplan het nie [He did not explain to the patient what his plans were at all]," and the impact it had on patients, "I mean most of the patients would come to the students afterwards and say I have no idea why I am here." 
Regarding the availability of good role models during their training, the participants revealed a variety of opinions. Some were generally positive - "Verseker! Daar was mense wat my baie beindruk het [Certainly! There were people that impressed me very much]"; others were fairly negative - "Maar jou rolmodelle is baie yl [But your role models are very sparse]." Some were also more satisfied than others:

En ek moet sê veral vir 'n paar uitsonderings het die doktors, dink ek goed [gedoen]. Dis nou my opinie. [And I must say that (barring) a few exceptions especially, I think the doctors did well. That is now my opinion.]

And we have a whole range of doctors at this hospital. Some are really bad. They have terrible bedside manners.

Paradoxically, poor role models illustrating "HOW NOT TO BE A DOCTOR [Student's capitalisation]," could have positive effects in that a student decided not to follow their behaviour. For example, in cases where doctors did not explain things to patients, a student observed, "Maar tot vandag toe is dit seker die grootste ding wat ek geleer [het], gaan net terug en sê vir hulle [die pasiënte] wat gaan aan. [But until this day it is perhaps the most important thing that I have learned: just go back and tell them (the patients) what is going on.]"

This by no means implies that such poor role models are somehow acceptable. Students may also imitate unprofessional behaviour, because, "It just migrates to you; this attitude just gets passed on." Furthermore, students also noticed that they had caught themselves perpetuating unwanted behaviour: "Maar wat die slegte ding daarvan is dat jy jouself vang dat jy presies [dieselfde] ding doen. [But the bad thing about it is that you catch yourself doing exactly (the same) thing.]"

Poor role models also affected students emotionally. Their behaviour may leave students feeling belittled and demotivated.

The one thing that really comes in the way especially of learning anything is doctors that don't know how to talk to people. They don't know how to talk to sisters, they don't know how to talk to patients, and more especially they don't know how to talk to the students. That just sours up the ward round. From early in the morning until you're finished. You don't listen to anything and you've been ridiculed, you've been belittled and they just want to go proving that you don't know anything.

\section{Discussion}

According to Wright and Caresse, being clinically competent is essential, but not sufficient, to be a good role model. ${ }^{14}$ The current requirements and objectives of national and international professional boards for medical education programmes include the adequate development of soft skills related to professional behaviour. ${ }^{15-18}$ However, Elzubeir and Rizk highlighted that academic departments tended to make appointments on the basis of research skills and publications. ${ }^{5}$
These aspects were not considered important by students as far as role models were concerned. ${ }^{5}$

Students expect professional behaviour from their role models. In this regard, the findings from our study support Mufson. ${ }^{2}$ It is also in line with those considering good role models as being interpersonally skilled, dedicated, honest, respectful, having a positive attitude, a commitment to excellence and growth, as well as integrity and leadership. 5,14,19 Paukert found a tendency among students "to use epic terms for good clinical teachers: 'folk heroes'; 'legends'" 20, which is similar to expressions such as "He's everything!' used in our study. The effect of positive role models on career choice and choice of specialisation is well reported in the literature ${ }^{4,5,8}$ and in our study there were also indications of students being inspired by good role models "You walk out of that block you feel you want to become a [clinician in that department]."

Another theme that emerged strongly from our study is the effect of the treatment of students by their role models. ${ }^{14,21}$ Many medical students and interns are exposed to poor role models, often through the unprofessional and unethical behaviour of doctors. ${ }^{13,22,23}$ Over and above that, "preregistration house officers experience poor support, inadequate supervision, humiliation, bullying and sexual discrimination on top of long hours and sleep deprivation." ${ }^{13}$ Students and interns not only observe, but are also drawn into following the poor example $\mathrm{e}^{22,23}$ and "this attitude just gets passed on". In this regard Pope states: "It is unsurprising that the medical profession harbours bullies, misogynists, and inadequate teachers if trainee doctors continue to be inspired by their experiences in the pre-registration year." ${ }^{23}$

As a result of this treatment, medical students may become distressed, confused, angry ${ }^{13}$, and find themselves with "an internal struggle that detracts from the medical school experience."'22 Paukert expresses the sentiment that "the relative absence of role models deprives interns of learning from example". ${ }^{20}$ Some participants in our study referred to the negative emotional impact that impedes learning where "you don't listen to anything". There were, however, also references to resistance to this kind of behaviour by drawing on values internalised as part of their own upbringing.

Issues reported in the literature as important for becoming a good role model that did not emerge strongly from our study were the teaching skills of role models and the time spent with learners. ${ }^{14,21}$ The fact that time spent with students is important may help explain the importance of registrars as role models. In the context of medical education in South Africa consultants are often involved in the formal lecturing of students, whereas the registrars supervise a lot of students' clinical practical work. Paice and associates make it clear that, for good role modelling to be sufficient, it must be supported by explicit teaching. ${ }^{13}$

\section{Conclusion}

Medical students develop their soft skills in a variety of settings during the six years of training. The fact that students following two different curricula assigned such a similar prominent influence to role models illustrates the centrality of role models in the professional socialisation of future physicians, regardless of the curriculum approach followed. It is therefore important to ensure that adequately trained clinical teachers are assigned to 
students, and that medical teachers are made aware of the influence they have on their future colleagues. An attempt should also be made to ensure that in addition to clinical examination skills, soft skills are demonstrated at the bedside with the full awareness of the teacher.

Particularly important is to make provision for the development of strategies to ensure adequate exposure of students to positive role models. These may include: more intensive staff development, especially with regard to the development of soft skills; the identification of good role models to guide new registrars in a more structured way; and a reallocation of tasks, where possible, to increase the exposure of students to 'natural' role models.

\section{Acknowledgements}

This publication would not have been possible without the willingness and openness of the students who participated in this study. The financial, professional and logistic support of the Departments of Obstetrics and Gynaecology and Psychiatry, the Education Office and the Deputy Dean's Office of the Faculty of Health Sciences is acknowledged with gratitude. The views expressed in this paper are those of the authors and not necessarily those of the sponsors. Ethical approval for conducting this study was given by the Research Ethics Committee of the Faculty of Health Sciences, University of Pretoria (No S183/2001).

\section{Declaration of Interest}

Willem Schurink was paid for his participation and consultation work by funds from the departments mentioned above.

\section{References}

1. Krüger C, Bergh A-M, Roos JL, Joubert PM, Du Preez R, Van Staden $W$, et al. Development of "soft skills" by undergraduate medical students: first findings from a University of Pretoria qualitative research project. Faculty Day poster presentation, School of Medicine, Faculty of Health Sciences, University of Pretoria, 27 August 2003.

2. Mufson MA. Professionalism in medicine: the department chair's perspective on medical students and residents. Am J Med 1997; 103:253-255.

3. Maudsly RF. Role models and the learning environment: essential elements in effective medical education. Acad Med 2001; 76:432434.

4. Basco WT, Reigart JR. When do medical students identify careerinfluencing physician role models? Acad Med 2001; 76:380-381.

5. Elzubeir M, Rizk DE. Identifying characteristics that students, interns and residents look for in their role models. Med Educ 2001; 35:272-277.
6. Shapiro J. How do physicians teach empathy in the primary care setting? Acad Med 2002; 77:323-328.

7. Reynolds PP. Reaffirming professionalism through the education community. Ann Internal Med 1994; 120:609-614.

8. Paukert JL, Richards BF. How medical students and residents describe the roles and characteristics of their influential clinical teachers. Acad Med 2000; 75:843-845.

9. Bogdan R, Biklen SK. Qualitative research for education. An introduction to theory and methods. Allyn \& Bacon. Boston. 1998

10. Glaser BG. Strauss AL. The discovery of grounded theory: strategies for qualitative research. Aldine De Gruyter. New York. 1967.

11. Schurink WJ. Qualitative research: introducing key features of an interpretive approach to social science research. Lecture Three: Considerations when choosing a qualitative style of research. Department of Human Resource Management, RAU: Johannesburg. 2004.

12. Strauss A, Corbin J. 1990. Basics of grounded theory procedures and techniques. CA: Sage. Newbury Park. 1990.

13. Paice E, Heard S, Moss F. How important are role models in making good doctors? BMJ 2002; 325:707-710.

14. Wright SM, Caresse JA. Serving as a physician role model for a diverse population of medical learners. Acad Med 2002; 78:623628.

15. HPCSA (Health Professions Council of South Africa). Education and training of doctors in South Africa: undergraduate medical education and training. Pretoria: Education Committee of the Medical and Dental Professional Board, HPCSA; 1999.

16. GMC (General Medical Council, UK). Tomorrow's doctors: recommendations on undergraduate medical education. London: GMC; 2003

17. Schwarz MR, Wojczak A. Global minimum essential requirements: a road towards competence-oriented medical orientation. Medical Teacher 2002; 24:125-129.

18. Simpson JG, Furnace J, Crosby J, Cummings AD, Evans PA, Friedman Ben David M, et al. The Scottish doctor - learning outcomes for the medical undergraduate in Scotland: a foundation for competent and reflective practitioners. Medical Teacher 2002; 24:136-143.

19. Côté L, Leclère H. How clinical teachers perceive the doctor-patient relationship and themselves as role models. Acad Med 2000; 75:1117-1124.

20. Paukert JL. From medical student to intern: where are the role models? JAMA 2001; 285:2781

21. Wright SM, Kern DE, Koldner K, Howard D, Brancati F. Attributes of excellent attending-physician role models. N Engl J Med 1998; 339:1986-1993.

22. Satterwhite RC, Satterwhite WM III, Enarson C. An ethical paradox: the effect of unethical conduct on medical students' values. J Med Ethics 2000; 26:462-465.

23. Pope C. No one forgets a bad teacher. Med Educ 2003; 36:5-6. 